\title{
The Neogene strombid gastropod Persististrombus in the Paratethys Sea
}

\author{
Mathias Harzhauser and Gijs C. Kronenberg \\ Acta Palaeontologica Polonica 58 (4), 2013: 785-802 doi: http://dx.doi.org/10.4202/app.2011.0130
}

Strombids are frequent fossils in Neogene nearshore deposits but are rarely used for biostratigraphy due to their poorly defined stratigraphic ranges. Herein, we document the biostratigraphic value of the group based on a succession of short-lived distinct species in Neogene deposits in the circum-Mediterranean area. These have been intermingled so far into two "super-species", viz. Persististrombus bonelli and P. coronatus, seemingly ranging from the Oligocene to the Pliocene. Based on morphometric measurements on 219 specimens we refine the taxonomic concept for this group and document at least 5 distinct species of high biostratigraphic and biogeographic significance. European Persististrombus species display a tendency to produce strongly sculptured populations with marked spines or to form populations with elongate shells and reduced sculpture. The development of sculptured morphs is an iterative process as exceptionally sculptured taxa occur in stratigraphically and geographically discrete phases and areas. Yet, within these species the morphology is very variable. Although some of these taxa are distinct species, there is no continuous evolutionary lineage leading to the Pliocene $P$. coronatus with which some of these taxa were confused in the literature so far. Successfully reproducing populations of extant species of Persististrombus in the Panamic Province and the African-Eastern Atlantic Province are limited in their distribution by the $20^{\circ \complement} \mathrm{C}$ isotherm. This value may thus be a realistic estimate for the cool-season sea surface temperatures for Persististrombus-bearing formations. Persististrombus pannonicus sp. nov. is established for a late Badenian species.

Key words: Gastropoda, Strombidae, Persististrombus, paleobiogeography, Miocene, Paratethys Sea, Mediterranean Sea.

Mathias Harzhauser [mathias.harzhauser@nhm-wien.ac.at], Geological-Paleontological Department, Natural History Museum Vienna, Burgring 7, A-1010 Vienna, Austria; Gijs C. Kronenberg [gijs.kronenberg@ncbnaturalis.nl], NCBNaturalis, P.O. Box 9517, NL-2300 RA Leiden, The Netherlands. 
This is an open-access article distributed under the terms of the Creative Commons

Attribution License (for details please see creativecommons.org), which permits unrestricted use, distribution, and reproduction in any medium, provided the original author and source are credited.

Fof Full text $(890.2 \mathrm{kB})$ 